\title{
BCR/ABL modulates protein phosphorylation associated with the etoposide-induced DNA damage response
}

\author{
François Griaud, Andrew J.K. Williamson, Samuel Taylor, David N. Potier, Elaine Spooncer, \\ Andrew Pierce, Anthony D. Whetton*
}

Stem Cell and Leukaemia Proteomics Laboratory, Manchester Academic Health, Science Centre, The University of Manchester, Wolfson Molecular Imaging, Centre, 27 Palatine Road, Withington, Manchester, M20 3LJ, UK

\section{A R T I C L E I N F O}

\section{Article history:}

Received 23 April 2012

Accepted 2 June 2012

Available online 15 June 2012

Keywords:

$\mathrm{BCR} / \mathrm{ABL}$

DNA damage

Hemogen

$\mathrm{NF} \kappa \mathrm{B}$

Phosphosite

\begin{abstract}
A B S T R A C T
$\mathrm{BCR} / \mathrm{ABL}$ expression is the key characteristic of chronic myeloid leukaemia (CML). The progression of CML is associated with genomic instability. Systematic analysis of DNA damage signalling in the presence of $\mathrm{BCR} / \mathrm{ABL}$ thus offers opportunities to identify mechanisms of leukaemic progression. We therefore undertook a quantitative phosphoproteomics study to test whether BCR/ABL expression could globally affect the response to genotoxic stress signalling. Etoposide-induced DNA damage was chosen and the concentration and time of exposure determined such that apoptosis was not associated with the study. More than 1100 phosphoentities were identified. BCR/ABL was shown to significantly alter the response to etoposide in many cases. These include sites on MDC1, a key component of DNA repair, and Hemogen. Hemogen is a transcriptional target of HOXB4 and GATA1, two transcription factors involved in haemopoietic development, and is overexpressed in acute myeloid leukaemia. To validate Hemogen phosphorylation, absolute quantification using an isotopomeric standard and selected reaction monitoring was performed. This revealed a strong correlation with isobaric tagging data and offering quantification at about $10 \mathrm{fmol}$ per million cells. Furthermore we found that multiple protein phosphorylation changes mediated by BCR/ABL were connected to the increased activation of $\mathrm{NF} \kappa \mathrm{B}$, a key survival transcription factor, after etoposide exposure.
\end{abstract}

(c) 2012 Elsevier B.V. All rights reserved.

\section{Introduction}

$\mathrm{BCR} / \mathrm{ABL}$ protein tyrosine kinase (PTK) is the hallmark of chronic myeloid leukaemia (CML) and emanates from the chromosomal translocation $t(9 ; 22)$ ( $q 34 ; q 11)$ leading to the expression of the dysregulated ABL PTK activity. BCR/ABL modulates multiple signalling pathways to promote cell survival and proliferation [1]. CML is a progressive disease and it has been proposed that genomic instability mediated by $\mathrm{BCR} / \mathrm{ABL}$ could promote disease progression to blast crisis [2], indeed chromosomal abnormalities are associated with BCR/ ABL expression and disease progression [3]. Genomic instability could be mediated by increased reactive oxygen species seen in the presence of leukaemogenic PTKs and concomitant

\footnotetext{
Abbreviations: AML, acute myeloid leukaemia; CML, chronic myeloid leukaemia; DSBs, double strand breaks; NFkB, nuclear factor kappa B; PTK, protein tyrosine kinase; $\mathrm{TiO}_{2}$, titanium dioxide; NHEJ, non-homologous end joining; HR, homologous recombination; SSA, single-strand annealing.

* Corresponding author. Tel.: +44 161275 0038; fax: +44 1612750003.

E-mail address: Tony.whetton@manchester.ac.uk (A.D. Whetton).
} 
DNA damage [4]. The modulation of DNA repair mechanisms by leukaemogenic PTKs has been established in a number of studies [2,4-7], BCR/ABL has also been shown to affect nonhomologous end joining (NHEJ) by increasing the rate of degradation of DNA-PKCs [8], whilst stimulating the alternative NHEJ pathway via Parp-1, DNA ligase III, CtIP nuclease and WRN helicase overexpression [2,9-11]. BCR/ABL expression has also been shown to increase the rate of homologous recombination (HR) by multiple mechanisms. For instance BCR/ABL increases Rad51 protein expression through STAT5mediated transcription, Rad51 phosphorylation on tyrosine 315 and Rad51 reduced proteolysis by inactivation of caspase 3 [6]. WRN and CtIP have also been shown to alter HR in the presence of BCR/ABL $[9,11]$. BCR/ABL can also enhance singlestrand annealing (SSA), possibly by WRN and CtIP overexpression $[4,9,11,12]$. BCR/ABL may also alter early DNA damage signalling and checkpoints to delay the $\mathrm{S}$ and $\mathrm{G} 2 / \mathrm{M}$ cell cycle phases to allow DNA misrepair [13,14]. Moreover $\mathrm{BCR} / \mathrm{ABL}$ signalling resists apoptosis after DNA damage $[6,7,15]$. The analysis of events following from the most dangerous form of DNA damage for the organism, double strand breaks, can throw further light on processes of mutagenesis $[6,7]$ especially if via the use of objective methods such as phosphoproteomics.

It remains the case that as yet unidentified DNA repair proteins could be regulated by $B C R / A B L$ to be the source of genomic instability and disease progression. The use of isobaric tagging procedures to determine changes in protein phosphorylation offers a route into pathway analysis for modulation of DNA damage signalling by BCR/ABL. This approach is ameliorated by the use of phosphopeptide enrichment strategies [16]. Here we have taken such an approach and discovered a number of protein phosphorylation events initiated by etoposide (a genotoxic agent inducing DNA double strand breaks) that are modulated by BCR/ ABL. Here we have demonstrated that Hemogen, a protein overexpressed in acute myeloid leukaemia (AML) is phosphorylated on serine 380 upon etoposide exposure and this is exacerbated by BCR/ABL to a great extent as the NFkB activity.

\section{Experimental procedures}

\subsection{Cell culture}

$\mathrm{Ba} / \mathrm{F} 3$ cells were transfected with either an "empty" MSCV retroviral vector, or MSCV containing BCR/ABL as previously described [17]. The resultant cell lines were maintained in culture in Fischer's medium (Invitrogen, Paisley, UK) with 10\% (v/v) horse serum (Biowest, Nuaillé, France). Ba/F3-MSCV cells were grown in Fischer's medium with $10 \%$ (v/v) horse serum supplemented with $5 \%$ (v/v) mIL-3 (conditioned media from X63-Ag-653 cells).

\subsection{Measurement of DNA double strand breaks and apoptosis assay}

Binding of $\gamma \mathrm{H} 2 \mathrm{AX}$ antibody was used to monitor DNA DSBs by fluoresceine isothiocyanate (FITC) fluorescence intensity (Millipore, USA), using manufacturer's instructions. Apoptosis was measured by annexin $\mathrm{V}$ binding according to manufacturer's instructions (BD Pharmingen, USA). Both assays were undertaken on a BD FACSCalibur ${ }^{\text {TM }}$ flow cytometry (Becton Dickinson Biosciences, USA)

\subsection{Preparation of cellular nuclei}

Nuclear proteins were enriched using a kit from Active Motif (Rixensart, Belgium) with some modifications. Briefly, $1 \times 10^{7}$ cells were washed in ice cold Hanks buffer $(136.7 \mathrm{mM} \mathrm{NaCl}$, $5.35 \mathrm{mM} \mathrm{KCl}, 0.812 \mathrm{mM} \mathrm{MgSO}_{4}, 1.28 \mathrm{mM} \mathrm{CaCl}_{2}$, $5.5 \mathrm{mM}$ Glucose, $24 \mathrm{mM}$ Hepes, pH 7.4) with protein phosphatase inhibitors and then lysed in hypotonic buffer $(500 \mu \mathrm{l})$ as per manufacturer's instructions. Enriched nuclei were then lysed on ice for $20 \mathrm{~min}$ in $75 \mu \mathrm{l} \mathrm{TEAB} 1 \mathrm{M}, 0.05 \%$ (w/v) SDS and $0.5 \mu \mathrm{l}$ of protease inhibitor cocktail (Active Motif) and $2 \mu \mathrm{l} / \mathrm{ml}$ Benzonase (Novagen, UK). The preparations were mixed, centrifuged for $10 \mathrm{~min}$ at $14,000 \times \mathrm{g}$ and the supernatant (nuclear fraction) recovered. The quality of the preparations was confirmed using western blot analysis for nuclear (Histone H3) and cytosolic ( $\alpha$ tubulin) standard marker proteins.

\subsection{Isobaric tagging for 8 channel analysis}

Nuclear proteins $(100 \mu \mathrm{g})$ from each cell line were reduced, alkylated, and subjected to tryptic hydrolysis prior to labelling with 8 channel isobaric tagging iTRAQTM reagent (AB Sciex, Warrington $\mathrm{UK}$ ) in $1 \mathrm{M}$ TEAB, according to the manufacturer's instructions (in all experiments isobaric labelling exceeded 99\% of total identified peptides using mass spectrometry, see below). Isobarically tagged peptides were then subjected to phosphopeptide enrichment on $\mathrm{TiO}_{2}$ columns.

\section{5. $\mathrm{TiO}_{2}$ mediated enrichment of phosphopeptides}

A hundred micrograms of nuclear iTRAQ $^{\mathrm{TM}}$ labelled peptide were mixed dried down and then re-suspended in $150 \mu \mathrm{l}$ of lactate loading buffer $(240 \mathrm{mg} / \mathrm{ml}$ lactate in $80 \%$ (v/v) acetonitrile, $1 \%(\mathrm{v} / \mathrm{v})$ Trifluoro-acetic acid (TFA). $\mathrm{TiO}_{2}$ columns (TopTip, Glygen Corp, USA) were equilibrated with $150 \mu \mathrm{l}$ of lactate loading buffer then the samples loaded. The tip was washed twice with $60 \mu \mathrm{l}$ of lactate loading buffer and four times with $60 \mu \mathrm{l}$ of wash buffer $(80 \%(\mathrm{v} / \mathrm{v})$ acetonitrile, $5 \%(\mathrm{v} / \mathrm{v})$ TFA). Bound peptides were then recovered by elution in $60 \mu \mathrm{l}$ of elution buffer (ammonium water [ $20 \mu \mathrm{l} \mathrm{NH} \mathrm{N}_{3}$ in $980 \mu \mathrm{l} \mathrm{H} \mathrm{H}_{2} \mathrm{O}$, $\mathrm{pH}$ 10.5). Samples were then concentrated to a few $\mu \mathrm{l}$ in a SpeedVac prior to High $\mathrm{pH}$ Reversed Phase chromatography.

\subsection{High $\mathrm{pH}$ Reversed Phase chromatography}

Prior to reversed phase LC-MS/MS peptides were fractionated off line using a reversed phase chromatography column (Fortis technologies, C18 $3 \mathrm{~mm} \mathrm{100/4.6} \mathrm{Reversed} \mathrm{phase} \mathrm{col-}$ umn) at a high pH using an LC Packings Ultimate LC system. The gradient was run at $700 \mu \mathrm{l} / \mathrm{min}$ using initially $99.5 \%$ high $\mathrm{pH}$ buffer A (0.1\% Ammonium hydroxide, adjusted to $\mathrm{pH} 10.5$ with formic acid) $0.5 \%$ high pH buffer B (0.1\% Ammonium hydroxide, $99.9 \%$ acetonitrile). Over a $30 \mathrm{~min}$ time period high $\mathrm{pH}$ buffer B was increased to $50 \%$, followed by a 4 min time period to increase high $\mathrm{pH}$ buffer $\mathrm{B}$ to $75 \%$. The concentration of high pH buffer B (75\%) was held for 4 min then reduced back down to $0.5 \%$. Fifteen second fractions were collected for the 
duration of the gradient, the volume of each fraction was then decreased under vacuum.

\subsection{Mass spectrometry}

Peptides were analysed using a QSTAR® XL or QSTAR® Elite (AB Sciex, Warrington, UK). For the QSTAR® XL, appropriate fractions from off-line fractionation were resuspended in $180 \mu \mathrm{l}$ of buffer A [Acetonitrile 2\% (v/v), Formic Acid 0.1\% (v/v)] and $60 \mu \mathrm{l}$ was loaded onto an on-line column (15 cm length; $75 \mu \mathrm{m}$ inner diameter) packed with RP $\mathrm{C}_{18}$ PepMap100 $(3 \mu \mathrm{m}$, $100 \AA$ ) using a UltiMate ${ }^{\mathrm{TM}}$ pump (LC Packings, Amsterdam, Netherlands) and separated at $250 \mathrm{nl} / \mathrm{min}$ over a $90 \mathrm{~min}$ solvent gradient from $5.9 \%(\mathrm{v} / \mathrm{v})$ acetonitrile/0.1\% (v/v) formic acid to $41 \%(\mathrm{v} / \mathrm{v})$ acetonitrile/0.1\% (v/v) coupled to a QSTAR® XL mass spectrometer (AB Sciex, Warrington, UK), followed by 30 min of washing and column re-equilibration. Data were acquired using an information dependent acquisition (IDA), designed with Analyst QS 2.0 (AB Sciex, Warrington, UK) which selected in the MS scan the two most abundant multiply charged peptides (2+ to $4+$ ) above a 20 count threshold with $\mathrm{m} / \mathrm{z}$ between 400 and 2000 for MS/MS and this for each cycle of the acquisition. Each ion was selected a maximum of two times and was then dynamically excluded $( \pm 50 \mathrm{mmu}$ ) for $1 \mathrm{~min}$. Phosphopeptiderich fractions were dried down and reanalysed using a QSTAR® Elite (AB Sciex, Warrington, UK). Fractions were resuspended in $10 \mu \mathrm{l}$ of $3 \%(\mathrm{v} / \mathrm{v})$ acetonitrile, $0.1 \%(\mathrm{v} / \mathrm{v})$ formic acid and $20 \mathrm{mM}$ citric acid. Five $\mu$ l of these fractions were loaded for $5 \mathrm{~min}$ at $15 \mu \mathrm{l} / \mathrm{min}$ onto a nanoACQUITY UPLC Symmetry $C_{18}$ Trap $(5 \mu \mathrm{m}$, $180 \mu \mathrm{m} \times 20 \mathrm{~mm}$ ) piloted with MassLynx ${ }^{\mathrm{TM}}$ (Waters, Manchester, $\mathrm{UK})$. Analytical separation of the peptides was performed at $300 \mathrm{nl} / \mathrm{min}$ using a nanoACQUITY UPLC BEH C ${ }_{18}$ Column $(1.7 \mu \mathrm{m}$, $75 \mu \mathrm{m} \times 250 \mathrm{~mm}$ ) over a $91 \mathrm{~min}$ solvent gradient from 3\% (v/v) acetonitrile, $0.1 \%(\mathrm{v} / \mathrm{v})$ formic acid to $40 \%(\mathrm{v} / \mathrm{v})$ acetonitrile, $0.1 \%$ (v/v) formic acid. Data were acquired using an information dependant acquisition (IDA) designed with Analyst $\circledast$ software QS 2.0 (AB Sciex, Warrington, UK) which selected for each cycle the four most abundant multiply charged peptides (2+ to $4+$ ) in the MS scan above a 10 count threshold with $\mathrm{m} / \mathrm{z}$ between 400 and 2000. Each ion was selected a maximum of two times and was dynamically excluded ( $\pm 50 \mathrm{mmu}$ ) for $90 \mathrm{~s}$ thereafter.

\subsection{Data analysis}

Spectra from QSTAR® XL and Elite were searched separately using ProteinPilot ${ }^{\mathrm{TM}} \mathrm{v} 3$ software (Paragon version 3.0.0.0, 113442 with default settings, AB SCIEX, Framingham, USA) to identify and quantify peptides as well as proteins from the Ensembl (FIXME reference, www.ensembl.org) murine "ens_mus_musculus_core_58.fasta" database containing 115,658 protein entries (species Mus musculus and "Thorough" search effort). Identification focus was on biological modifications with phosphorylation emphasis as a special factor. Search parameters included iTRAQ ${ }^{\mathrm{TM}}$ 8plex modification at peptide level, cysteine alkylation with MMTS, trypsin digestion, QSTAR® Elite ESI as instrument for the QSTAR® Elite ESI and QSTAR® ESI for the QSTAR® XL. A global false discovery rate (FDR) was performed using a decoy database and determined at $2.4 \%$ for the QSTAR® XL and $0.2 \%$ for the QSTAR® Elite searches for peptides identified with $20 \%$ confidence. Ratio values for each phosphoentity were obtained from weighted averages of multiple spectra when appropriate, similarly to the way ProteinPilot ${ }^{\mathrm{TM}}$ calculate ratios for proteins. The minimum iTRAQ ${ }^{\mathrm{TM}}$ reporter ion area used for quantification was set at 20 (arbitrary units). Weighted ratios were log-averaged for the 244 phosphoentities identified with both QSTAR® XL and QSTAR® Elite. ProteinPilot ${ }^{\mathrm{TM}}$ biases were used to correct for any sampling error so that the median value of $\log _{2}$ (ratios) of the phosphoentity distribution is equal to 0 for each pair of iTRAQ ${ }^{\mathrm{TM}}$ reagents. The distribution of the biological replicates Control(2): Control(1) was used to determine the biological variability of the procedure by combining the 4 control ratios $\operatorname{MSCV}(2): \operatorname{MSCV}(1)$, MSCV +Etoposide(2):MSCV +Etoposide(1), BCR/ABL(2):BCR/ABL(1) and BCR/ABL+Etoposide(2):BCR/ABL+Etoposide(1). Student's ttest was performed between the values of 2 biological replicates for each appropriate ratio and the gaussian distribution of the biological replicates Control(2):Control(1). Phosphoentities determined as potentially changing had a Student's t-test pvalue $<0.05$ in appropriate ratiometric analysis. Phosphoentities changing between the two controls, i.e. for Control(2):Control(1) ratio, with a $\mathrm{p}$-value $<0.05$ were manually removed from the analysis.

\subsection{Selected Reaction Monitoring of a Hemogen Heavy Labelled peptide}

Absolute Quantification (AQUA ${ }^{\mathrm{TM}}$ ) experiments were performed with a 4000 QTRAP® (Applied Biosystems, FUSA) mass spectrometer coupled to a liquid chromatography system consisting of a Famos autosampler, a Switchos trap system and an Ultimate Plus dual pump (LC Packings, Dionex, Sunnyvale, CA). Peptides were resuspended in buffer $\mathrm{A}[97.9 \%(\mathrm{v} / \mathrm{v})$ water, $2 \%(\mathrm{v} / \mathrm{v})$ acetonitrile and $0.1 \%$ (v/v) formic acid] and washed onto a trap $\mathrm{C}_{18}$ column (LC Packings, Dionex, Sunnyvale, CA). Peptide elution was then performed using a gradient of buffer B [79.9\% (v/v) acetonitrile, $20 \%(\mathrm{v} / \mathrm{v})$ water and $0.1 \%(\mathrm{v} / \mathrm{v})$ formic acid] and passed through an analytical $\mathrm{C}_{18}$ column (Acclaim pepmap 100, $15 \mathrm{~cm}$, pore size $100 \AA$ Å) from Dionex (LC Packings, Dionex, Sunnyvale, CA). The LC system and the mass spectrometer were piloted with Chromeleon 6.50 SP4 Build 1000 and Analyst 1.5.1 (Applied Biosystems, Foster City, CA), respectively.

Limit of detection of the Hemogen AQUA ${ }^{\text {TM }}$ phosphopeptide (EFTVPIVSsQK ${ }^{*}, \mathrm{~K}^{*}=\mathrm{K}+8 \mathrm{Da}$ ) (New England Peptide LLC, Gardner, MA, USA) was assessed by analysing in triplicate 0,1 , $5,10,50,100$ and $500 \mathrm{fmol}$ prepared in $55 \mu \mathrm{l}$ of buffer A [97.9\% $(\mathrm{v} / \mathrm{v})$ water, $2 \%(\mathrm{v} / \mathrm{v})$ acetonitrile and $0.1 \%(\mathrm{v} / \mathrm{v})$ formic acid]. Quantification was performed with the maximum intensity in counts per second (cps) of the extracted ion chromatogram (XIC) of the transition 662.0/846.5 (fragment $\mathrm{y}_{7}$ ), while two other transitions were used to confirm peptide identity, i.e. 662.0/748.5 (fragment $\mathrm{y}_{7}-\mathrm{H}_{3} \mathrm{PO}_{4}$ ) and 662.0/1046.6 (fragment у9). The equivalent transitions were created for the native peptide (Table 1). The method had a total cycle time of $1.64 \mathrm{~s}$.

Two $\mu \mathrm{g}(1.5 \mathrm{nmol})$ of the AQUA ${ }^{\mathrm{TM}}$ peptide were prepared in $100 \mu$ l of high $\mathrm{pH}$ buffer A to determine its elution time on the off-line $\mathrm{C}_{18}$ RP column. Nuclear protein extracts $(100 \mu \mathrm{g}$, equivalent to approximately 2 million $\mathrm{Ba} / \mathrm{F} 3$ cells) were digested with trypsin at $2 \mathrm{~g} / \mathrm{l}$ (Promega, Madison, WI, USA) overnight at $37^{\circ} \mathrm{C}$. Three biological replicates of each sample were prepared. Peptides were dried for $1 \mathrm{~h}$ under vacuum. Dried peptides were resuspended in $1 \mathrm{ml}$ of high $\mathrm{pH}$ buffer $\mathrm{A}$ and $250 \mathrm{fmol}$ of the 
Table 1 - Parameters used for selected reaction monitoring for the native and the AQUA'M Hemogen peptides.

\begin{tabular}{|c|c|c|c|c|c|c|c|}
\hline Peptide & Sequence $\left(K^{*}: K+8 \mathrm{Da}\right)$ & Precursor ion charge state & Q1 m/z (Th) & Q3 m/z (Th) & Fragment (1+) & Dwell time (ms) & $\mathrm{CE}(\mathrm{V})$ \\
\hline \multirow[t]{3}{*}{ AQUA ${ }^{T M}$} & EFTVPIVSpSQK ${ }^{*}$ & $2+$ & 662.0 & 846.5 & $\mathrm{y}_{7}$ & 400 & 32.1 \\
\hline & EFTVPIVSpSQK ${ }^{*}$ & $2+$ & 662.0 & 1046.6 & $\mathrm{y}_{9}$ & 200 & 32.1 \\
\hline & EFTVPIVSpSQK* & $2+$ & 662.0 & 748.5 & $\mathrm{y}_{7}-\mathrm{H}_{3} \mathrm{PO}_{4}$ & 200 & 32.1 \\
\hline \multirow[t]{3}{*}{ Native } & EFTVPIVSpSQK & $2+$ & 658.0 & 838.5 & $\mathrm{y}_{7}$ & 400 & 32 \\
\hline & EFTVPIVSpSQK & $2+$ & 658.0 & 1038.6 & $\mathrm{y}_{9}$ & 200 & 32 \\
\hline & EFTVPIVSpSQK & $2+$ & 658.0 & 740.5 & $\mathrm{y}_{7}-\mathrm{H}_{3} \mathrm{PO}_{4}$ & 200 & 32 \\
\hline
\end{tabular}

AQUA ${ }^{\text {TM }}$ peptide was spiked in before off-line fractionation with high $\mathrm{pH}$ reversed phase chromatography. Peptides were collected in a 2 min window comprising the AQUATM peptide elution time and were concentrated under vacuum before LCSRM analysis.

Collision energies (CE) for both the native and AQUA ${ }^{\mathrm{TM}}$ peptides were calculated using the following equation: $\mathrm{CE}=$ $[a \times(m / z)]+b$, where $a=0.044$ and $b=3.000$ are parameters for $a$ doubly charged peptide optimized for this particular instrument. The method was tested with $100 \%$ buffer A and $500 \mathrm{ng}$ of trypsinized nuclear material to assess the level of different backgrounds for all transitions. Additionally, the AQUA ${ }^{\mathrm{TM}}$ peptide did not trigger the transitions of the native peptide for the range of quantities injected for each sample $\left(<50 \mathrm{fmol}\right.$ of AQUA ${ }^{\mathrm{TM}}$ peptide). Dried peptides were resuspended in $165 \mu$ l of buffer A and analysis was performed with $55 \mu \mathrm{l}$. Q1 mass resolution was set at "low" and Q3 at "unit".

\subsection{Western blot}

Histone H3 (Cell Signaling Technology), $\alpha$-Tubulin, Hemogen (M-180 and T-20) (Santa Cruz Biotechnology) and H2AX pTyr 142 (Millipore) were used for western blotting using standard procedures.

\subsection{NF $\kappa B$ luciferase assay}

$\mathrm{Ba} / \mathrm{F} 3$ cells (+/- BCR/ABL) were transfected using the Amaxa cell line transfection kit $\mathrm{V}$ (Lonza) with $2 \mu \mathrm{g}$ of $\mathrm{NF} \kappa \mathrm{B}$-Firefly luciferase plasmid and 2 ng of Thymidine kinase-Renilla luciferase plasmid for normalization. Twenty-four hours after transfection, cells were exposed to etoposide $(20 \mu \mathrm{M})$ for $20 \mathrm{~min}$, washed and left to recover for $24 \mathrm{~h}$. Firefly and Renilla luciferase activity was measured by Dual Luciferase reporter assay (Promega) on a luminometer Flash n'glow (Berthold).

\section{Results}

\subsection{Induction of DNA damage and DNA repair with etoposide}

In order to perform an analysis of the combinatorial effects of $\mathrm{BCR} / \mathrm{ABL}$ and etoposide on hematopoietic cells we first determined the concentration and time of exposure to etoposide that gave limited apoptosis in MSCV and BCR/ABL expressing $\mathrm{Ba} / \mathrm{F} 3$ cells. Etoposide is known to induce DNA damage causing mainly DNA double strand breaks (DSBs), although it may also generate DNA single-strand breaks at low concentrations [18]. MSCV and $\mathrm{BCR} / \mathrm{ABL}$ expressing $\mathrm{Ba} / \mathrm{F} 3$ cells were treated with a range of etoposide concentrations for set times, after this they were washed and placed into fresh medium containing IL-3. The percentage of apoptotic cells was then determined by Annexin V staining at $24 \mathrm{~h}$ (Fig. 1A and B). Apoptosis increased over time of exposure to etoposide and with increased dose of etoposide as anticipated, however MSCV Ba/F3 cells were more susceptible to apoptosis. Incubation of cells with etoposide for $24 \mathrm{~h}$ shows an anti-apoptotic effect promoted by BCR/ABL ( $p$-values of 0.041 , 0.041 and 0.004 for 20, 40 and $80 \mu \mathrm{M}$ respectively).

To ensure etoposide was inducing DNA DSBs in these conditions in both MSCV and BCR/ABL-expressing cells, the DNA DSB-specific phosphorylation of histone H2AX at serine $139(\gamma \mathrm{H} 2 \mathrm{AX})$ was monitored using flow cytometry. DNA DSBs increased with etoposide concentration (Fig. 1C) and incubation time (Fig. 1D) in both MSCV and BCR/ABL cells. The majority of MSCV and BCR/ABL expressing cells were positive for $\gamma \mathrm{H} 2 \mathrm{AX}$ phosphorylation within 20 min of treatment with etoposide concentrations above $40 \mu \mathrm{M}$. Apoptosis remained at low levels after $20 \mathrm{~min}$ exposure to $20 \mu \mathrm{M}$ etoposide despite $60 \%$ to $70 \%$ of cells showing DNA damage (Fig. 1C). Hence these conditions were used for subsequent experimentation to ensure we were predominantly looking at DNA repair induced signalling rather than apoptosis.

To characterize potential DNA DSB repair, a kinetic study was performed to evaluate the decrease of $\gamma \mathrm{H} 2 \mathrm{AX}$ phosphorylation. After DNA DSBs induction by $20 \mu \mathrm{M}$ etoposide for $20 \mathrm{~min}$, MSCV and $\mathrm{BCR} / \mathrm{ABL}$ expressing cells were washed, replated into fresh medium and allowed to recover for $1 \mathrm{~h}$. Over this period of time, some DNA DSBs were repaired in MSCV Ba/F3 cells, as shown by the decrease of anti- $\gamma \mathrm{H} 2 \mathrm{AX}$ median fluorescence (Fig. 1E), while the amount of DNA DSBs was steady and remained high in the presence of BCR/ABL. The difference in DNA DSBs between MSCV and $B C R / A B L$ expressing cells was found to be significant ( $p$ value $=0.0079$ using the non-parametric Mann-Whitney $U$ test). These observations suggest that either the recruitment of DNA repair proteins to the site of DNA DSBs may be modulated by BCR/ ABL or that this leukaemogenic PTK could modulate DNA damage response signalling. This led us to examine phosphorylation changes in response to etoposide in the presence and absence of BCR/ABL.

\subsection{Phosphoproteomic analysis of etoposide-induced events in the presence and absence of $B C R / A B L$}

We have shown above that BCR/ABL expressing cells have a differential rate of DSB repair to MSCV expressing cells (Fig. 1E). The reasons for this are likely to be pleiotropic and as such we investigated this using mass spectrometry. The appropriate conditions determined above were employed, $20 \mu \mathrm{M}$ etoposide for $20 \mathrm{~min}$ to enable differences between MSCV and BCR/ABL 

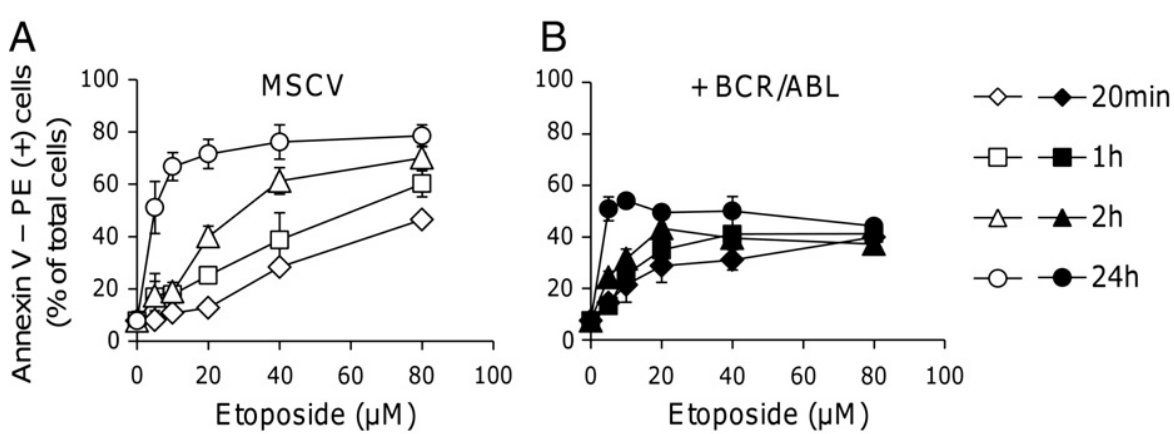

C
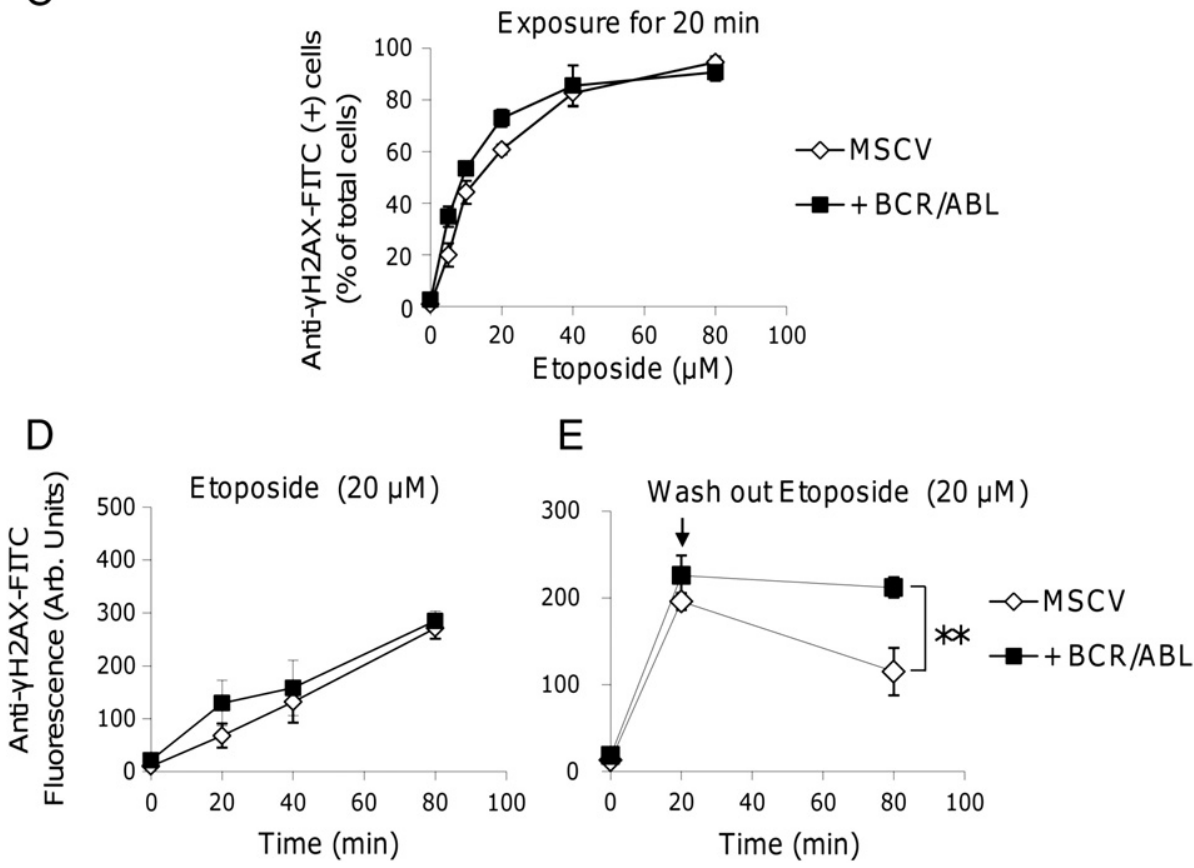

Fig. 1 - Etoposide-induced DNA double strand breaks and apoptosis in $\mathrm{Ba} / \mathrm{F} 3$ cells in presence or absence of BCR/ABL. DNA double strand breaks (DSBs) were induced in MSCV (A) and BCR/ABL (B)-expressing Ba/F3 cells by etoposide at 5, 10, 20, 40 and 80 $\mu \mathrm{M}$ for $20 \mathrm{~min}, 1 \mathrm{~h}$ and $2 \mathrm{~h}$ then cells were washed and left for $24 \mathrm{~h}$ in fresh medium supplemented with mIL-3. A positive control was performed with $24 \mathrm{~h}$ incubation with etoposide. Apoptosis was quantified by flow cytometry using Annexin V-PE and 7-AAD. Percentages of total Annexin V-PE positive (+) cells, i.e. total apoptotic cells, were averaged from three independent biological replicates. (C) DNA DSBs were induced with etoposide at 5, 10, 20, 40 and $80 \mu \mathrm{M}$ for $20 \mathrm{~min}$ in MSCV and BCR/ABL-expressing cells. The percentage of anti- $\gamma$ H2AX-FITC positive cells was determined above the fluorescence of the untreated population. Data displayed correspond to average values of three independent biological replicates. (D) DNA DSBs were induced in MSCV and BCR/ ABL-expressing cells by etoposide at $20 \mu \mathrm{M}$ for 20,40 and $80 \mathrm{~min}$ and were quantified (median fluorescence) by flow cytometry using the anti- $\gamma \mathrm{H} 2 \mathrm{AX}$-FITC assay. (E) Both MSCV and BCR/ABL-expressing cells were grown in a medium supplemented with mIL-3 $16 \mathrm{~h}$ before the experiment. DNA DSBs were induced in MSCV and BCR/ABL-expressing cells by etoposide at $20 \mu \mathrm{M}$ for $20 \mathrm{~min}$, then cells were washed from etoposide and left for $1 \mathrm{~h}$ in fresh medium supplemented with mIL-3. Anti- $\gamma \mathrm{H} 2 \mathrm{AX}-\mathrm{FITC}$ fluorescence corresponds to the average of the median values of the cell population fluorescence from five independent biological replicates. **Two-sided p-value of 0.007937 (values tend to be distributed differently) was obtained from a Mann-Whitney $U$ test (non-parametric test). (A, B, C, D, E) Error bars correspond to standard error of the mean (SEM).

expressing cells to be studied (see Fig. 2A for workflow). Subcellular fractionation was performed to ensure a deeper penetration into the nuclear proteome/phosphoproteome. Western blot analysis of Histone $\mathrm{H} 3$ and tubulin expression/ distribution was used as a measure of quality of the fractionation (Fig. 2B). A hundred micrograms of nuclear proteins were digested with trypsin, labelled with iTRAQ ${ }^{\text {TM }}$ reagent (isobaric labelling exceeded $99.9 \%$ of all peptides identified) and phosphopeptides enriched with $\mathrm{TiO}_{2}$. Peptides were fractionated with
high-pH reverse phase chromatography before LC-MS/MS analysis. The number of phosphopeptides detected was 1114 with a false discovery rate (FDR) of $2.4 \%$ for the QSTAR® XL and $0.2 \%$ for the QSTAR® Elite. The data acquired showed a normal distribution between biological replicates with a modal value of 1.0 (linear scale) or 0.0 (logarithmic scale) for all iTRAQ ${ }^{\text {TM }}$ relative ratios (Fig. 2C).

To determine if etoposide exposure and/or BCR/ABL expression resulted in a change for each phosphopeptide an 
unpaired two-sample Student's t-test, under the assumption of equal variance, was applied to relevant iTRAQ ${ }^{\mathrm{TM}}$ ratios. When the mean of 2 independent replicates was outside the ratio interval $[-0.44 ; 0.44]$ with a Student's t-test $p$-value $<0.05$ in appropriate $\mathrm{ITRAQ}^{\mathrm{TM}}$ ratios this was considered as a change and included in the data set of changing phosphopeptides.

Response to both BCR/ABL and/or etoposide in Ba/F3 cells was analysed using hierarchical clustering (supplementary Fig.
1). In this way the response of BCR/ABL and MSCV expressing cells to etoposide could be compared. This revealed a trend of decreased response to etoposide in a subset of proteins (Fig. 3, top panel and supplementary Table 1). Downstream targets of BCR/ABL expressing cells (Fig. 3, middle panel and supplementary Table 2) and BCR/ABL-modulated etoposide signalling (Fig. 3, bottom panel and supplementary Table 3) were also identified. The analysis revealed 112 distinct phosphopeptides
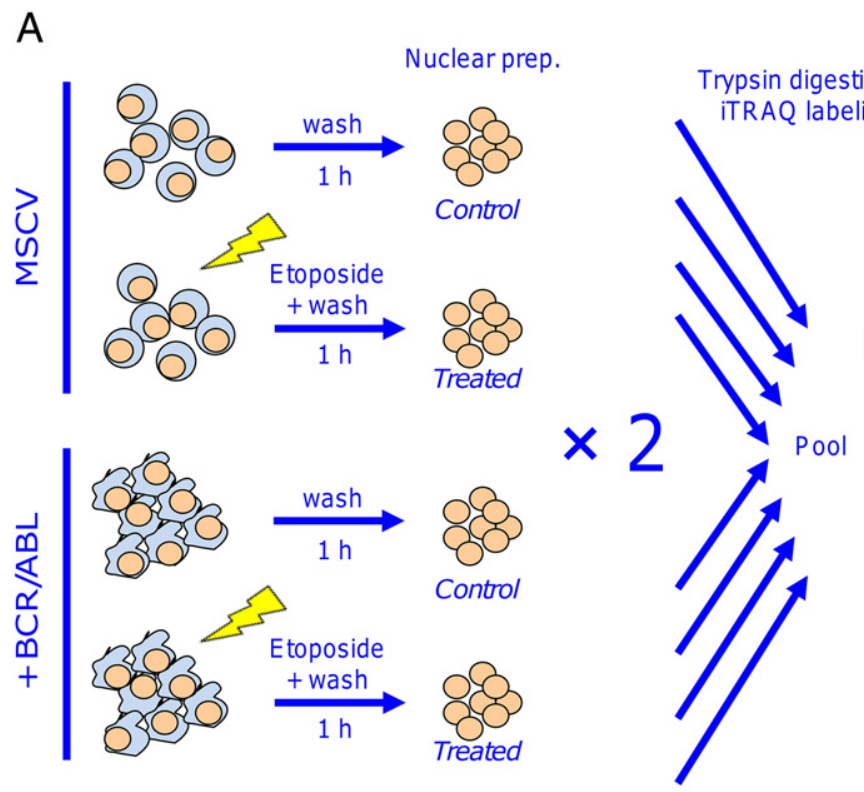

Trypsin digestion \&

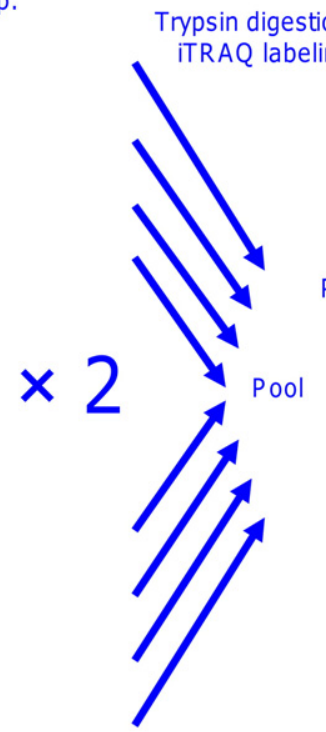

Phosphopeptide
enrichment
$\left(\mathrm{TiO}_{2} / \mathrm{RP}\right)$

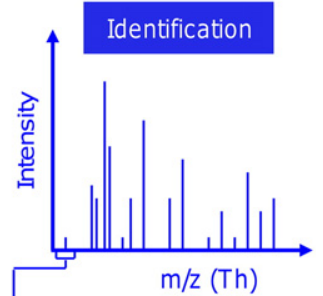

Quantification

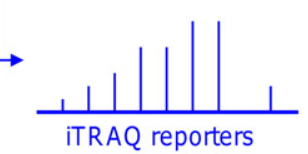

B

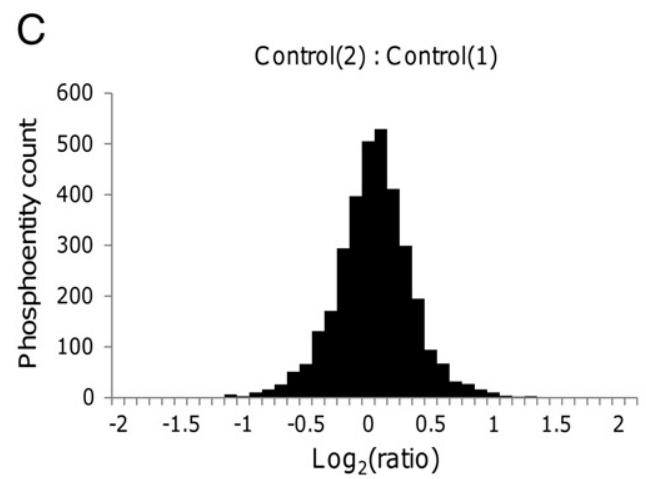

Fig. 2 - Schematic workflow of the phosphosite-specific proteomic analysis of etoposide-induced nuclear effects in Ba/F3 cells in presence and absence of BCR/ABL. (A) Schematic representation of the work flow. MSCV and BCR/ABL expressing cells were generated from biological replicates to produce eight nuclear extracts treated or not with etoposide $(20 \mu \mathrm{M})$ for $20 \mathrm{~min}$. (B) Following isolation $15 \mu \mathrm{g}$ of nuclear $(\mathrm{N})$ and $45 \mu \mathrm{g}$ of cytoplasmic (C) lysates were separated by SDS PAGE and the distribution of Histone $\mathrm{H} 3$ and tubulin assessed by western blot analysis. (C) Composite distribution of the phosphoentity (confidence $>20 \%$ ) $\log _{2}$ (ratio) for the Control(2):Control(1) combining the 4 control ratios MSCV(2):MSCV(1), MSCV + Etoposide(2): MSCV + Etoposide(1), BCR/ABL(2):BCR/ABL(1) and BCR/ABL + Etoposide(2):BCR/ABL + Etoposide(1) for both QSTAR® XL and QSTAR $®$ Elite. All control ratios of phosphoentities identified with a sequence confidence above $20 \%$ were transformed with the logarithmic function at the base 2 (the distribution of the ratios was plotted against bins ranging from -2 to 2 ). 
showing changes for BCR/ABL and/or etoposide action (Student's t-test $\mathrm{p}$-value $<0.05$ ). Among them 41 specific phosphopeptides were regulated by etoposide but not BCR/ABL and 27 by BCR/ABL but not etoposide. Finally, 44 distinct phosphopeptides were regulated by both etoposide and $B C R / A B L$, that is to say there was an overlap between BCR/ABL and genotoxic stress signalling in these cases (supplementary Table 3). Evidence of regulation by etoposide and BCR/ABL on single and/or multiple phosphosites was obtained for 21 proteins whereas phosphorylation modulation by BCR/ABL signalling only and etoposide response only could be detected on 20 and 21 proteins, respectively (supplementary Tables 1 and 2). For example BCR/ABL potentiated phosphorylation on proteins involved in transcription (Myc, Jun), RNA processing/splicing (Pabpn1, Hnrnpc), ribosome biogenesis (Dkc1, Nop56), translation initiation (Eif5b), nuclear trafficking (Nup35, Ranbp2), PI3K pathway (Inpp5d, Dok1), superoxide production (Ncf2), DNA ligation (DNA ligase) and epigenomic regulators (histone methyltransferase Whsc1, histone demethylase Kdm2a) (supplementary Table 2).

\section{3. $\quad B C R / A B L$ expression modulates etoposide response}

We employed phosphopeptide analysis to discern if BCR/ABL grossly affected genotoxic stress induced nuclear signalling. The data demonstrate that this is the case. In the first instance we identified that several phosphopeptides from proteins associated with DNA damage were regulated by etoposide exposure. For example, the histone H2AX was phosphorylated on serine 139 by etoposide (Fig. 3, top panel) [19]. Also, the ATM and NBS1-dependent SMC3 phosphorylation on serine 1083, required for intra-S phase checkpoint, was also observed following DNA damage (Fig. 3, top panel) [20,21]. MDC1 and 53BP1, key proteins in the response to DNA damage, were also regulated. Two phosphosites (serine 549 and threonine 906) of 53BP1 were also found to be regulated (supplementary Table 1), while MDC1 serine 929 was dephosphorylated upon etoposide exposure (Figs. 3, 4A and B). Although the functions of these sites have not been described, 53BP1 and MDC1 remain key regulators of DNA damage response [22,23]. These data validate
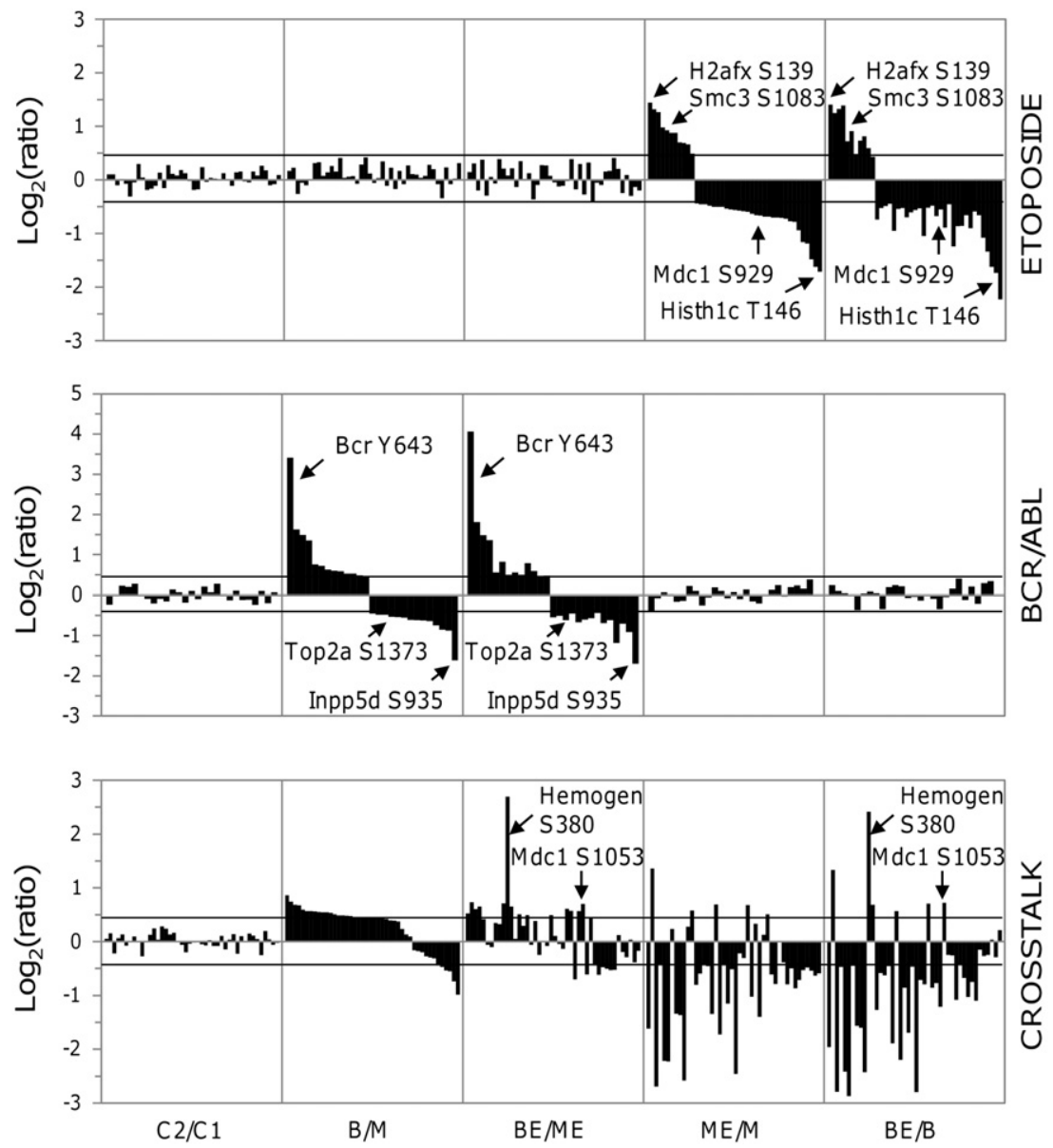

Fig. 3 - Protein changes induced by BCR/ABL expression and/or etoposide treatment. The average of 2 biologically independent $\log _{2}$ (ratio) is shown for each phosphoentity found to be significantly different (two-sided Student's t-test $p$-value $<0.05$, i.e. outside the range [-0.44;0.44]) from the mean of the composite distribution Control(2):Control(1) in appropriate ratios [BCR/ABL: MSCV (B/M), BCR/ABL + Etoposide:MSCV + Etoposide (BE/ME), MSCV + Etoposide:MSCV (ME/M) and BCR/ABL + Etoposide:BCR/ABL (BE/B)]. Average of control values is also shown for each phosphoentity [Control(2):Control(1) (C2/C1)]. Phosphoentities are sorted according to their regulation by etoposide, BCR/ABL or both (crosstalk). 
the approach taken to uncover novel forms of oncogene/ genotoxic stress response.

As described above, 44 specific phosphopeptides were found to be regulated by BCR/ABL. Thirty-one of these phosphoentities were regulated by $\mathrm{BCR} / \mathrm{ABL}$ and modulated further by etoposide, while 13 showed a modulation of response to etoposide in presence of the oncogene (supplementary Table 3). These data demonstrate $\mathrm{BCR} / \mathrm{ABL}$ has multiple effects on genotoxic stress signalling. In summary $\mathrm{BCR} / \mathrm{ABL}$ affected the response of $\mathrm{Ba} / \mathrm{F} 3$ cells to etoposide in a number of ways: modulating the intensity of the response; blocking or creating a phosphorylation change in response to etoposide (supplementary Table 3 ). In addition to the regulation observed on MDC1 serine 929 with etoposide, MDC1 serines 595 and 1053 were modulated by both BCR/ABL

A 2

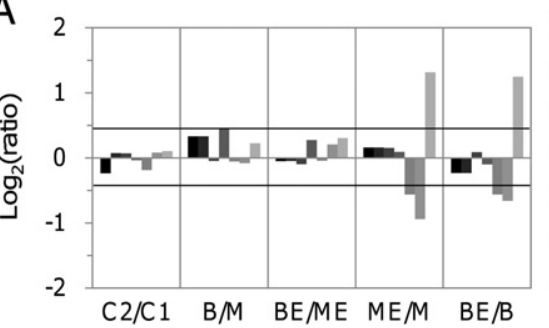

- $53 b p 1$ S 267

- $53 \mathrm{bp} 1 \mathrm{~S} 268$

- 53bp1 $\mathrm{S} 382$

- 53bp1 T384

- 53bp1 S552

- 53bp1 S555

- 53bp1 T912

B

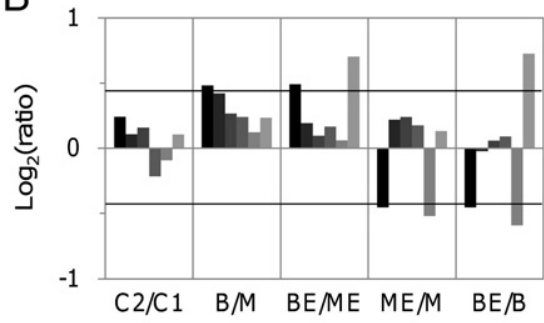

- Mdc1 S595

- Mdc1 T749

- Mdc1 S750

- Mdc1 T782

- Mdc1 S929

Mdc1 S1053

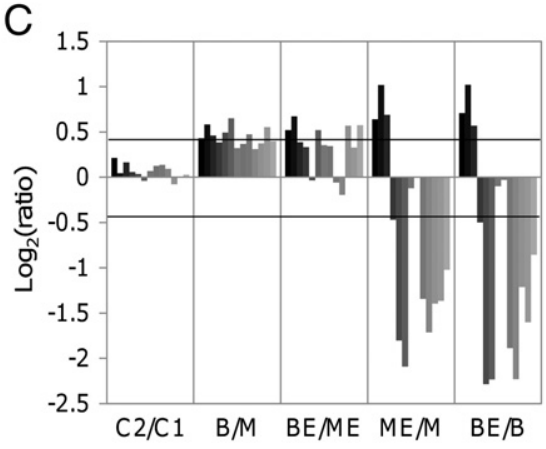

- Hist1h1a T4

- Hist1h1d T4

- Hist1h1e T4

- Hist1h1b S18

- Hist1h1d T18

- Hist1h1e T18

- Hist1h1c/d S36/37

- Hist1h1e T35

- Hist1h1b T135

- Hist1h1c/d T146/147

- Hist1h1a S183

- Hist1h1b S186

- Hist1h1e T187

Fig. 4 - Protein phosphorylation dynamics induced by BCR/ ABL expression and/or etoposide treatment.

Phosphorylation dynamics are shown for multiple phosphosites of $53 \mathrm{bp} 1$ (A), Mdc1 (B) and several Histone H1 variants (Histh $1 \mathrm{a} / \mathrm{b} / \mathrm{c} / \mathrm{d} / \mathrm{e}$ ) (C) upon etoposide exposure and BCR/ABL expression. Average of 2 biologically independent $\log _{2}$ (ratio) is shown for each protein phosphosite (average of all relevant phosphoentities) and ratios of interest [BCR/ABL: MSCV (B/M), BCR/ABL + Etoposide:MSCV + Etoposide (BE/ME), MSCV + Etoposide:MSCV (ME/M) and BCR/ABL + Etoposide: $B C R / A B L(B E / B)]$. Significant difference (two-sided Student's t-test $p$-value $<0.05$ ) with the mean of the composite distribution Control(2):Control(1) is found outside the range $[-0.44 ; 0.44]$, delineated by straight lines. and etoposide (Fig. 4B). BCR/ABL effects on serine 595 phosphorylation were the opposite of those observed with etoposide. Conversely, serine 1053 was phosphorylated by etoposide exposure only in the presence of the oncogene. As a control

A

Hemogen pS380 (EFTVPIVSS[Pho]QK)

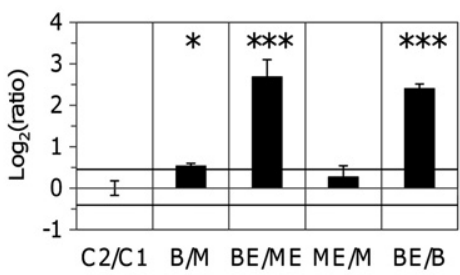

B

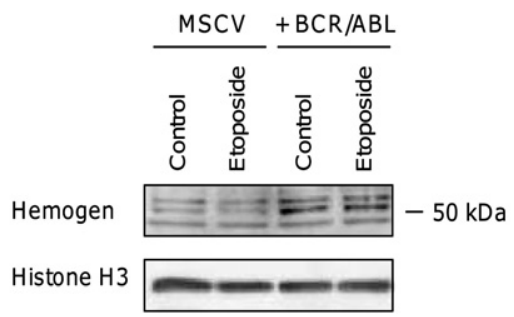

C

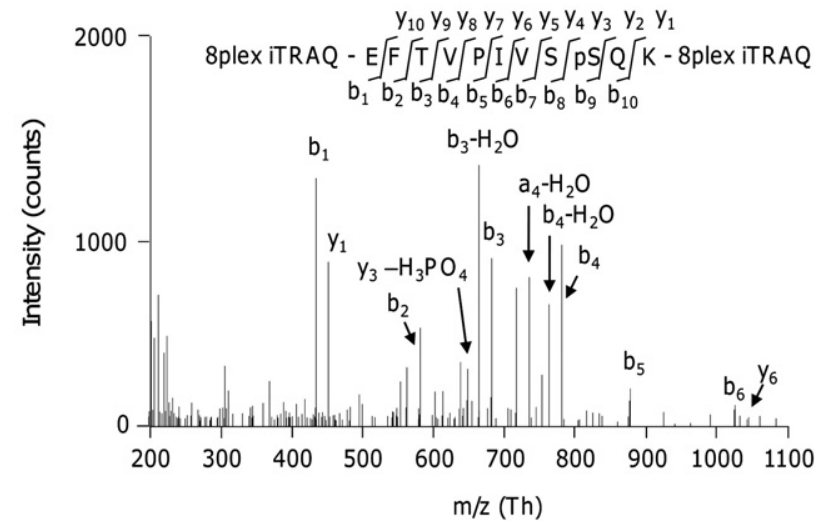

Fig. 5 - Hemogen phosphorylation on serine 380 upon etoposide exposure and BCR/ABL expression. (A) MSCV and $\mathrm{BCR} / \mathrm{ABL}$-expressing $\mathrm{Ba} / \mathrm{F} 3$ cells were treated with etoposide $(20 \mu \mathrm{M})$ or medium for $20 \mathrm{~min}$ and collected $1 \mathrm{~h}$ after post drug/control washout. Average of $\log _{2}$ (ratios) is shown for the biological control Control(2):Control(1) (C2/C1) and ratios of interest [BCR/ABL:MSCV (B/M), BCR/ABL + Etoposide: MSCV + Etoposide (BE/ME), MSCV + Etoposide:MSCV (ME/M) and BCR/ABL + Etoposide:BCR/ABL (BE/B)]. Error bars correspond to SEM. Significance level for Student's t-test $\mathrm{p}$-value (p): ${ }^{*} \mathrm{p}<0.05$, and ${ }^{* * *} \mathrm{p}<0.001$. (B) Hemogen protein expression in nuclear extracts before and after etoposide exposure in MSCV and BCR/ABL-expressing Ba/F3 cells. Histone $\mathrm{H} 3$ was used as a loading control. (C) Hemogen pS380 spectra were identified with a QSTAR® Elite mass spectrometer and mapped to Hemogen pS380 by ProteinPilot $^{\mathrm{TM}}$ v3.0 software. Spectra were sequenced manually to confirm phosphosite assignment. Multiple ions of the $b$ ion series were identified, while the dephosphorylated form $\left(-\mathrm{H}_{3} \mathrm{PO}_{4}\right.$ : $\left.-98 \mathrm{Da}\right)$ of $\mathrm{y}_{3}$ fragment was identified in the 2 spectra assigned to this phosphopeptide. 
A
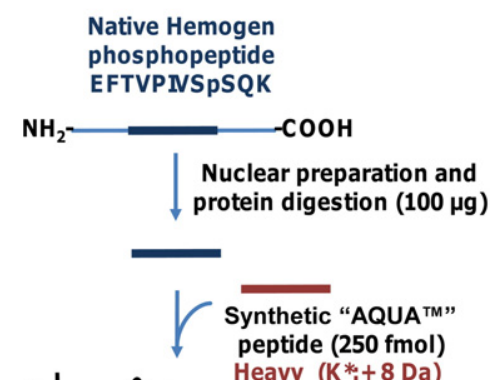

B
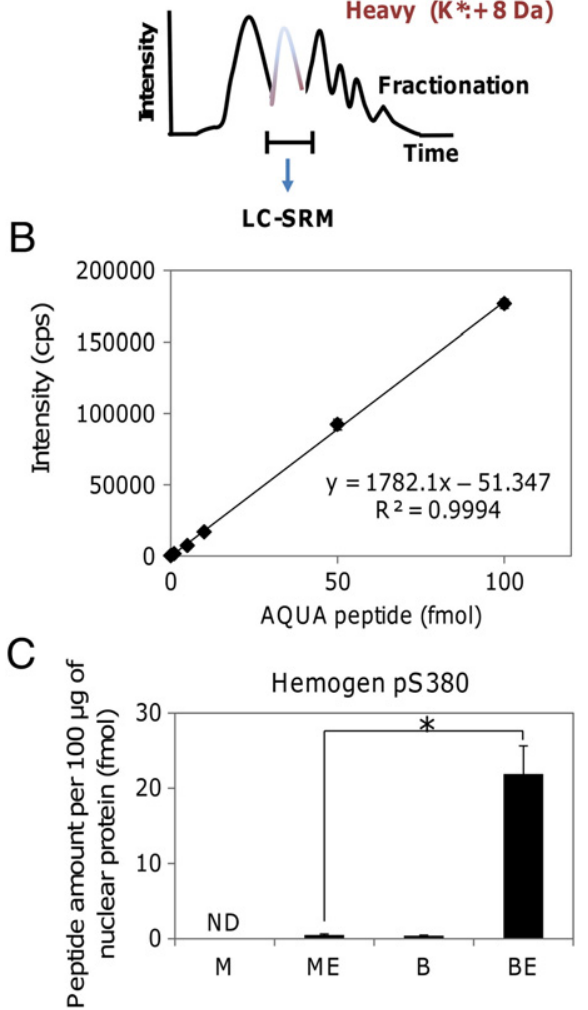

Fig. 6 - Absolute quantification (AQUA ${ }^{\mathrm{TM}}$ ) of Hemogen phosphorylation on serine 380. (A) Workflow used for AQUA ${ }^{\mathrm{TM}}$. A synthetic peptide (AQUA ${ }^{\mathrm{TM}}$ peptide) containing a stable isotope of lysine $\left(\mathrm{K}^{*}: \mathrm{K}+8 \mathrm{Da}\right)$ was designed to match the sequence EFTVPIVSPSQK ${ }^{*}$. After nuclear protein preparation and tryptic digestion of $100 \mu \mathrm{g}$ of protein, a known amount of the AQUA ${ }^{\text {TM }}$ peptide $(250 \mathrm{fmol})$ was added to the mixture. Off-line fractionation was performed to reduce sample complexity. Selected reaction monitoring (SRM) was then performed after liquid chromatography (LC) for absolute quantification. (B) Linear regression of an isotopic dilution of the AQUA $^{\text {TM }}$ peptide transition 662.0/846.5 (fragment ion $\mathrm{y}^{7}$ ) from 100 to 0 fmol in buffer A in triplicate. Error bars correspond to the standard error of the mean (SEM). (C) MSCV and BCR/ABLexpressing $\mathrm{Ba} / \mathrm{F} 3$ cells were treated with etoposide $(20 \mu \mathrm{M})$ or medium for $20 \mathrm{~min}$ and collected $1 \mathrm{~h}$ after post drug/control washout. Amount of the native phosphopeptide was inferred in each sample from the AQUA phosphopeptide known quantity using the pair of transitions 662.0/846.5 (AQUA ${ }^{\mathrm{TM}}$ peptide) and 658.0/838.5 (native peptide) each targeting the fragment ion $y^{7}$, using 3 independent biological replicates. Error bars correspond to the SEM. *Unpaired two-sided Student's t-test $p$-value $=0.029$. ND: not detected. M: MSCV, ME: MSCV +Etoposide, B: BCR/ABL, BE: BCR/ABL+Etoposide. indicating the observed changes relate to altered protein kinase/phosphatase action, MDC1 threonines 749 and 782 as well as serine 750 were not affected, either by BCR/ABL or etoposide (Fig. 4B).

One of the major sets of proteins affected was the histones in which numerous phosphosites were modified (Fig. 4C). Histone $\mathrm{H} 1$ threonine 4 was phosphorylated in response to etoposide but also $B C R / A B L$, suggesting oncogenic signalling maintains genotoxic stress signalling. Differences between histone $\mathrm{H} 1$ variants were also noted. Histone $\mathrm{H} 1$ response to etoposide led to dephosphorylation of threonine 18 , threonine 135, serine 183 (Histh1a), serine 186 (Histh1b) and threonine 187 (Histh1e), although these sites were upregulated by BCR/ ABL either prior or after etoposide treatment. Whilst the functional association of all these events is not known, H1 phosphorylation has been proposed to lead to a relaxation of chromatin structure due to a decreased affinity of this protein for chromatin after phosphorylation. The effect of BCR/ABL, therefore on Histone H1d T4 phosphorylation could alter DNA repair processes. However the critical point is the targeting of Histone phosphorylation by an oncogene in a way that overlaps to a great extent the effect of genotoxic stress. This offers further opportunities for consideration of mechanisms in genomic instability.

Hmga1, a protein involved in transcription regulation and overexpressed in presence of several leukaemogenic PTKs (Pierce, et al. unpublished data) was, additionally to its upregulation with BCR/ABL, dephosphorylated on serine 36 with etoposide as well as serines 99 and/or 103 specifically in presence of the oncogene, leading in both case to the nullification of their original modulation (supplementary Table 3). Conversely, the decrease observed with etoposide on Cbx3, p66-alpha (Gatad2a), Hnrnpc phosphoserines 93, 181, 229 and phosphothreonine 344 respectively, was more marked in presence of the oncogene, suggesting an amplification of genotoxic stress response on these phosphoresidues (supplementary Table 3). Also, phosphoentities were found to be modulated by BCR/ABL and etoposide on the p53 interactor Gnl3 (pS95), Stk10 (pT950), Incenp (pS284), Mybbp1a (pT1277 and pT1280) or Anln (pS318 and pS293) (supplementary Table 3).

The most marked effect we observed in terms of synergistic interaction was on the Hemogen protein and its phosphorylation on serine 380 (Fig. 5A). Hemogen is a transcriptional target of HOXB4 and GATA1, two transcription factors involved in haemopoietic development, and Hemogen expression itself can induce myelopoiesis and suppress lymphopoiesis in transgenic mice [24-26]. It has not been ascribed a function in genotoxic stress responses. Given the prominence of this effect we took the hemogen phosphorylation event as a paradigm to validate the iTRAQ ${ }^{\text {TM }}$ approach to altered phosphorylation status.

\subsection{A validation of the Hemogen Serine 380 phosphorylation}

As etoposide seemed to have a considerable effect on Hemogen phosphorylation at serine 380 in response to $\mathrm{BCR} / \mathrm{ABL}$ in $\mathrm{Ba} / \mathrm{F} 3$ cells, western blotting was used to confirm that Hemogen protein expression was not up-regulated by $\mathrm{BCR} / \mathrm{ABL}$ or etoposide (Fig. 5B). No such increase in total protein was seen following etoposide treatment in both MSCV and BCR/ABL expressing cells. However, Hemogen protein expression was 
higher in the presence of BCR/ABL. Plainly this cannot account for the increased level of EFTVPIVSS[Pho]QK in BCR/ABL cells when etoposide is added. The ITRAQ ${ }^{\mathrm{TM}}$ approach is suited to discovery proteomics but the underestimation of fold change by ITRAQ $^{\text {TM }}$ is a phenomenon previously described [27]. As linear ratiometric values for the effects of $B C R / A B L$, etoposide in MSCV cells and etoposide in BCR/ABL-expressing cells were 1.45 (Student's t-test p-value: 0.013), 1.21 (p-value: 0.199$)$ and 5.33 ( $\mathrm{p}$-value: $2.99 \times 10^{-27}$ ) respectively (Fig. $5 \mathrm{~A}$ ), the next issue was to develop a means of verifying the observed effect and addressing the underestimation from iTRAQ ${ }^{\text {TM}}$-based method. This was achieved by the absolute quantification (AQUA ${ }^{\mathrm{TM}}$ )-mediated assessment of effects on S380 Hemogen. Critically, phosphosite assignment was first confirmed and is demonstrated in Fig. 5C.

Based on these Hemogen data, a heavy-labelled version of the phosphopeptide (AQUA ${ }^{\mathrm{TM}}$ peptide) was designed with a mass increase of $8 \mathrm{Da}$ compared to the native peptide. The same amount of the AQUA ${ }^{\mathrm{TM}}$ peptide was spiked in different tryptic digests of nuclear proteins from $\mathrm{Ba} / \mathrm{F} 3$ cells (treated or not with etoposide and in presence or absence of BCR/ABL). Three biological replicates, prepared as previously described, were used. Phosphopeptides were fractionated off-line for each condition (Fig. 6A). Then relevant fractions were combined and analysed on a 4000 QTRAP $尺$ mass spectrometer using SRM transitions designed for both the endogenous and heavy-labelled phosphopeptides. Three pairs of SRM transitions were designed to identify either the native or the AQUA $^{\mathrm{TM}}$ peptide and quantification was performed and improved for the most intense fragment ion ( $\left.\mathrm{y}_{7}\right)$. Typical examples for each individual sample are shown in Supplementary Fig. 2 for one set of biological replicates. Linear response of the intensity was confirmed between 0 and 100 fmol of the AQUA ${ }^{\mathrm{TM}}$ peptide for this transition, comprising the range of injection for both the native and the AQUA ${ }^{\text {TM }}$ peptide $(<50 \mathrm{fmol})$ (Fig. 6B) and a summary of quantification is shown in Fig. 6C.

The most striking observation was that in MSCV Ba/F3 cells we were unable to detect EFTVPIVSS[Pho]QK. Plainly this is at odds with the iTRAQ ${ }^{\mathrm{TM}}$ ratiometric data (Fig. 5A). Nonetheless the addition of etoposide to MSCV cells did increase EFTVPIVSS[Pho]QK levels to $0.25 \mathrm{fmol} / 10^{6}$ cells. When BCR/ABL was expressed the levels found were $0.2 \mathrm{fmol} / 10^{6}$ cells. When BCR/ ABL expressing cells were treated with etoposide the level went up a considerable degree ( 55 fold on average) compared to untreated BCR/ABL expressing cells. These AQUA ${ }^{\mathrm{TM}}$ data suggest $B C R / A B L+$ etoposide increase the number of copies of the EFTVPIVSS[Pho]QK phosphosite from Hemogen to approximately $6600(+/-1100)$ copies per cell.

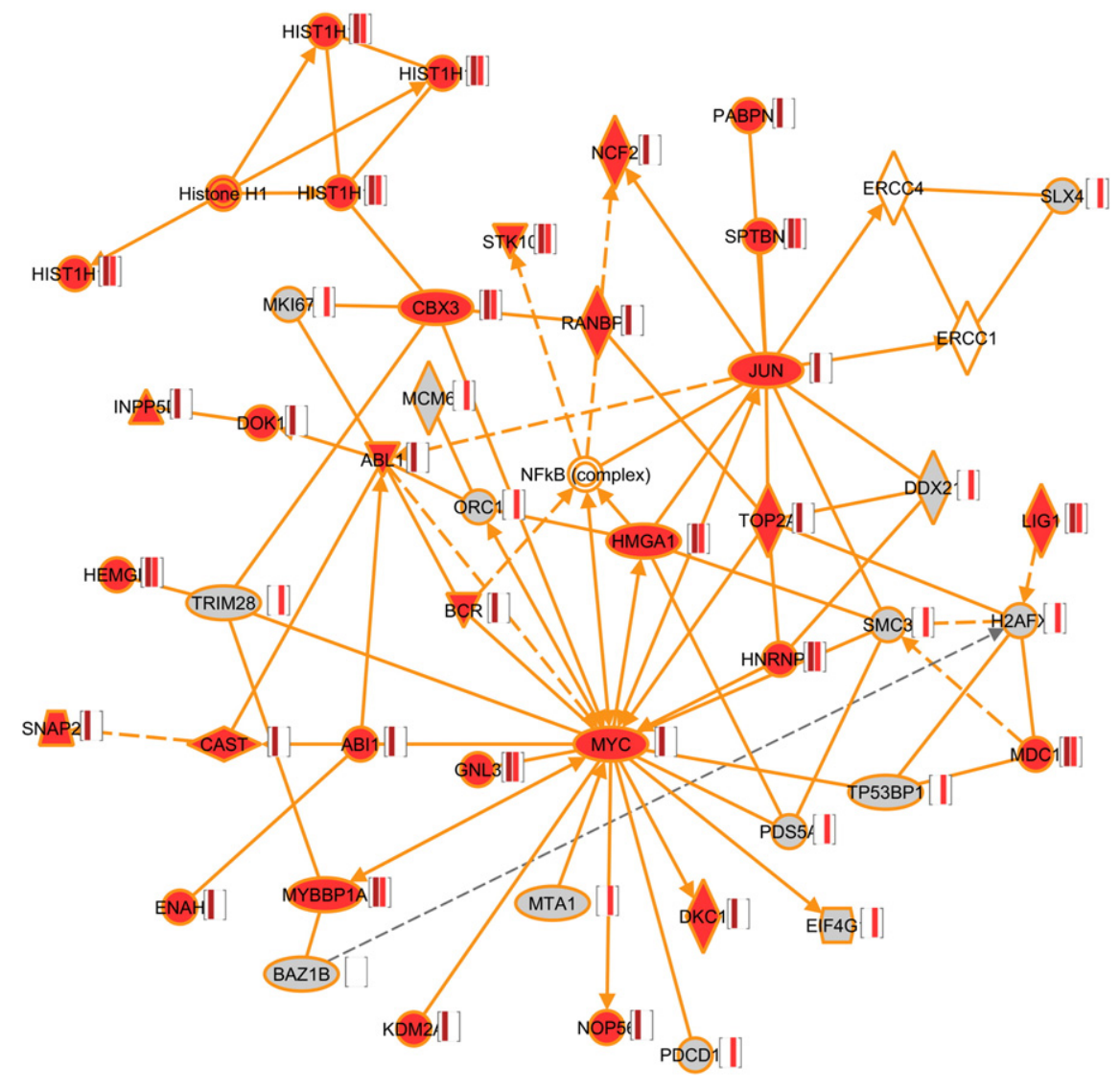

Fig. 7 - Annotated Ingenuity pathway analysis for proteins modulated by BCR/ABL and etoposide. This diagram was created using Ingenuity pathway analysis (connections in orange) (http://www.ingenuity.com). One connection was added in grey between the tyrosine kinase Baz1b and its substrate $\mathrm{H} 2 \mathrm{afx}(\mathrm{H} 2 \mathrm{AX})$ based on literature [30,31]. Bars in brackets are shown whenever a protein is regulated on one or multiple phosphosites by BCR/ABL (left crimson bar) or etoposide (right red bar). Proteins shown in red contain phosphoentities modulated by BCR/ABL. Proteins in grey correspond to other proteins identified in this study. Proteins in white were added to build the network. 


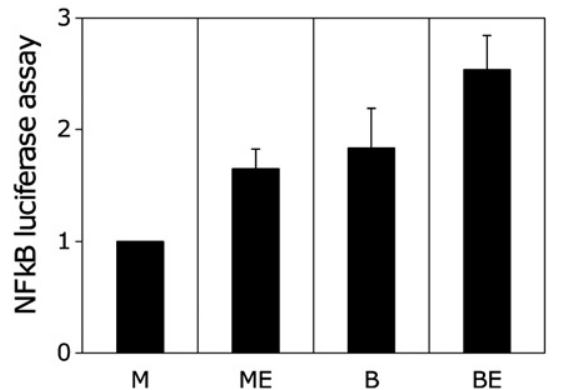

Fig. 8 - NF $\kappa$ B activation is induced by $B C R / A B L$ expression and etoposide treatment. MSCV and BCR/ABL-expressing $\mathrm{Ba} /$ F3 cells were transfected with $2 \mu \mathrm{g}$ of pNF $\kappa$ B-Firefly luciferase and $\mathbf{2} \mathrm{ng}$ of thymidine kinase-Renilla luciferase plasmids. Twenty-four hours post transfection cells were treated with etoposide $(20 \mu \mathrm{M})$ or medium for $20 \mathrm{~min}$ before washing and recovery for $24 \mathrm{~h}$. Cells were lysed and the level of NF $\kappa$ B activation measured by Firefly luciferase activity normalised to Renilla luciferase activity which is under control of constitutively active Thymidine kinase. Values shown are reported to untreated MSCV Ba/F3 cells. M: MSCV, ME: MSCV +Etoposide, B: BCR/ABL, BE: BCR/ABL + Etoposide. Data represent the average and error bars correspond to the standard error of the mean (SEM) of three independent biological replicates.

3.5. Pathway analysis pinpoints the B-WICH and NF- $\kappa \mathrm{B}$ complexes as potential mediators of BCR/ABL-mediated genomic instability

Pathway analysis was performed with the different proteins consistently regulated on phosphoentities by BCR/ABL and/or etoposide addition. The connections between a subset of proteins are shown in Fig. 7. Potential links between some of the proteins found to be regulated in this dataset (Stk10, Myc, Jun, Ranbp2, Hmga1) were noted with the NF-kB complex. More particularly Hemogen has been shown to induce the activation of NF-кB after growth factor removal [28]. We therefore performed a NF- $\kappa \mathrm{B}$ luciferase assay to determine the level of activation of $\mathrm{NF}-\kappa \mathrm{B}$ by $\mathrm{BCR} / \mathrm{ABL}$ and etoposide treatment. NF- $\kappa B$ activation was higher in the presence of the oncogene compared to MSCV and was at a level similar to MSCV cells post etoposide exposure, suggesting BCR/ABL maintains genotoxic stress signalling (Fig. 8). Moreover, NF$\kappa \mathrm{B}$ response was significantly higher when transformed cells were exposed to etoposide compared to treated MSCV cells (one-sided t-test p-value: 0.034). Interestingly, Mybbp1a has been shown to repress the NF- $\kappa$ B transcription factor [29], and was found regulated at multiple phosphosites (S6, T1277 and S1280) by BCR/ABL and/or etoposide (supplementary Tables 1 and 3). To the best of our knowledge, no particular role has been yet proposed for these phosphosites with regard to NF$\kappa \mathrm{B}$ repression. This particular protein belongs to the $\mathrm{B}-\mathrm{WICH}$ complex along with DDX21, also regulated in this study on S144 (S181). Mybbp1a and DDX21 regulations pinpointed the B-WICH complex as a potential node for the modulation of the DNA damage response. Baz1b/WSTF, another member of this complex, has been recently described as a new tyrosine kinase for
$\mathrm{H} 2 \mathrm{AX}$ on tyrosine 142 [30], close to $\gamma \mathrm{H} 2 \mathrm{AX}$ phosphorylation on serine 139. H2AX tyrosine 142 phosphorylation is an event required for apoptosis while its dephosphorylation promotes cell survival and DNA repair [31]. Western blot analysis suggested $\mathrm{H} 2 \mathrm{AX}$ tyrosine 142 is less phosphorylated in the presence of $\mathrm{BCR} /$ ABL (supplementary Fig. 3). NF- $\kappa B$ activation and reduced $\mathrm{H} 2 \mathrm{AX}$ tyrosine 142 , by modulation of the B-WICH complex or a phosphatase, in presence of BCR/ABL would promote cell survival and DNA (mis)repair to occur.

\section{Discussion}

The relationship between BCR/ABL and genotoxic stress signalling remains poorly understood. Only a few modulations of protein phosphorylation have been described in relation to their relevance to disease progression, treatment resistance, DNA repair fidelity or cell cycle progression $[6,7,14]$. Here, we described the use of 8plex iTRAQ ${ }^{\mathrm{TM}}$ reagents and titanium dioxide chromatography to perform phosphoproteomic comparison on multiple cell signalling pathways following oncogenic kinase expression and transient genotoxic stress response.

In this report, we identified that Hemogen phosphorylation on serine 380 was regulated by etoposide specifically with BCR/ABL. Interestingly, Hemogen was identified in the Heterochromatin protein $1 \alpha$ (HP1 $\alpha$ )-Chromatin-assembly factor 1 (CAF-1) complex along with Trim28/TIF-1beta/KAP-1 [32], involved in chromatin remodelling and DNA repair [33,34]. The strong induction of Hemogen phosphorylation would suggest that Hemogen may take part in some of these functions. Correlation between this phosphorylation event, survival advantage and DNA repair mechanisms will be a subject of further work. Importantly, this phosphosite is conserved in humans within a region of relatively high sequence variability. Murine Hemogen serine 380 (EFTVPIVSSQKTIQESP) would correspond to human serine 339 (EIIVPKAPSHKTIQETP). PhosphoMotif Finder indicates that this peptide contains a PKC consensus site and interestingly, PKC has been shown to mediate Hemogen expression during K562 cell differentiation [35].

In this report, we also identified complex protein phosphorylation dynamics on a subset of other proteins, e.g. Histone H1, MDC1, 53BP1 after etoposide treatment, some of them being modulated by the presence of BCR/ABL.

Of interest, MDC1 regulation on serine 595 by BCR/ABL, but not the etoposide response described here, has also been identified in another study using BCR/ABL and FLT3/ITDexpressing $\mathrm{Ba} / \mathrm{F} 3$ cells (Pierce, et al. unpublished data). Importantly, phosphorylation of MDC1 on serine 1053 specifically with both etoposide and BCR/ABL is found at the beginning of MDC1 PST domain which has been shown to be involved in the regulation of both NHEJ and HR $[23,36]$. MDC1 recruitment to H2AX for efficient DNA repair also depends on H2AX dephosphorylation on tyrosine 142 [30,31], decreased in BCR/ABLexpressing $\mathrm{Ba} / \mathrm{F} 3$ cells (supplementary Fig. 3). This modulation would orientate favourably and in a permanent way any genotoxic stress signalling towards survival and DNA (mis) repair. It remains hypothetical whether NF- $\kappa$ B activation following genotoxic stress and oncogenic signalling is directly linked with $\mathrm{H} 2 \mathrm{AX}$ dephosphorylation on tyrosine 142, through the possible modulation of the B-WICH complex or a phosphatase. 
In conclusion, this study identified several phosphorylation sites that $B C R / A B L$ could modulate with respect to their response to DNA damage induced by etoposide. BCR/ABL could sustain genotoxic stress signalling on several proteins and compromise the response of DNA repair proteins. Among these proteins, MDC1, H2AX and Hemogen might be the targets of BCR/ABL for the promotion of cell survival as well as DNA misrepair leading to genomic instability. Further study of the role of these modifications should be carried out to unravel the relevance of these crosstalks in leukaemia progression and chemotherapy resistance.

\section{Acknowledgements}

The authors would like to thank Drs Emma Carrick, Michael Walker and Cong Zhou for helpful discussions on data analysis. This work was supported by Leukaemia and Lymphoma Research UK. FG was additionally sponsored by the British Council with an Entente Cordiale scholarship.

\section{Appendix A. Supplementary data}

Supplementary data to this article can be found online at http://dx.doi.org/10.1016/j.jprot.2012.06.003.

\section{REFER E N C E S}

[1] Turner SD, Alexander DR. Fusion tyrosine kinase mediated signalling pathways in the transformation of haematopoietic cells. Leukemia 2006;20:572-82.

[2] Skorski T. BCR/ABL regulates response to DNA damage: the role in resistance to genotoxic treatment and in genomic instability. Oncogene 2002;21:8591-604.

[3] Dierov J, Sanchez PV, Burke BA, Padilla-Nash H, Putt ME, Ried $\mathrm{T}$, et al. BCR/ABL induces chromosomal instability after genotoxic stress and alters the cell death threshold. Leukemia 2009;23:279-86.

[4] Cramer K, Nieborowska-Skorska M, Koptyra M, Slupianek A, Penserga ETP, Eaves CJ, et al. BCR/ABL and other kinases from chronic myeloproliferative disorders stimulate single-strand annealing, an unfaithful DNA double-strand break repair. Cancer Res 2008;68:6884-8.

[5] Nowicki MO, Falinski R, Koptyra M, Slupianek A, Stoklosa T, Gloc E, et al. BCR/ABL oncogenic kinase promotes unfaithful repair of the reactive oxygen species-dependent DNA double-strand breaks. Blood 2004;104:3746-53.

[6] Slupianek A, Schmutte C, Tombline G, Nieborowska-Skorska M, Hoser G, Nowicki MO, et al. BCR/ABL regulates mammalian RecA homologs, resulting in drug resistance. Mol Cell 2001;8:795-806.

[7] Rink L, Slupianek A, Stoklosa T, Nieborowska-Skorska M, Urbanska K, Seferynska I, et al. Enhanced phosphorylation of Nbs1, a member of DNA repair/checkpoint complex Mre11-RAD50-Nbs1, can be targeted to increase the efficacy of imatinib mesylate against BCR/ABL-positive leukemia cells. Blood 2007;110:651-60.

[8] Deutsch E, Dugray A, AbdulKarim B, Marangoni E, Maggiorella L, Vaganay S, et al. BCR-ABL down-regulates the DNA repair protein DNA-PKcs. Blood 2001;97:2084-90.

[9] Salles D, Mencalha AL, Ireno IC, Wiesmueller L, Abdelhay E. BCR-ABL stimulates mutagenic homologous DNA double-strand break repair via the DNA-end-processing factor CtIP. Carcinogenesis 2011;32:27-34.

[10] Sallmyr A, Tomkinson AE, Rassool FV. Up-regulation of WRN and DNA ligase III alpha in chronic myeloid leukernia: consequences for the repair of DNA double-strand breaks. Blood 2008;112:1413-23.

[11] Slupianek A, Poplawski T, Jozwiakowski SK, Cramer K, Pytel D, Stoczynska E, et al. BCR/ABL stimulates WRN to promote survival and genomic instability. Cancer Res 2011;71:842-51.

[12] Fernandes MS, Reddy MM, Gonneville JR, DeRoo SC, Podar K, Griffin JD, et al. BCR-ABL promotes the frequency of mutagenic single-strand annealing DNA repair. Blood 2009;114:1813-9.

[13] Slupianek A, Hoser G, Majsterek I, Bronisz A, Malecki M, Blasiak J, et al. Fusion tyrosine kinases induce drug resistance by stimulation of homology-dependent recombination repair, prolongation of $\mathrm{G}(2) / \mathrm{M}$ phase, and protection from apoptosis. Mol Cell Biol 2002;22:4189-201.

[14] Nieborowska-Skorska M, Stoklosa T, Datta M, Czechowska A, Rink L, Slupianek A, et al. ATR-Chk1 axis protects BCR/ABL leukemia cells from the lethal effect of DNA double-strand breaks. Cell Cycle 2006;5:994-1000.

[15] McGahon A, Bissonnette R, Schmitt M, Cotter KM, Green DR, Cotter TG. Bcr-Abl maintains resistance of chronic myelogenous leukemia cells to apoptotic cell death. Blood 1994;83:1179-87.

[16] Lee CF, Griffiths S, Rodriguez-Suarez E, Pierce A, Unwin RD, Jaworska E, et al. Assessment of downstream effectors of $\mathrm{BCR} / \mathrm{ABL}$ protein tyrosine kinase using combined proteomic approaches. Proteomics 2010;10:3321-42.

[17] Pierce A, Unwin RD, Evans CA, Griffiths S, Carney L, Zhang L, et al. Eight-channel iTRAQ enables comparison of the activity of six leukemogenic tyrosine kinases. Mol Cell Proteomics 2008;7:853-63.

[18] Montecucco A, Biamonti G. Cellular response to etoposide treatment. Cancer Lett 2007;252:9-18.

[19] Rogakou EP, Pilch DR, Orr AH, Ivanova VS, Bonner WM. DNA double-stranded breaks induce histone H2AX phosphorylation on serine 139. J Biol Chem 1998;273:5858-68.

[20] Luo H, Li Y, Mu J-J, Zhang J, Tonaka T, Hamamori Y, et al. Regulation of intra-S phase checkpoint by ionizing radiation (IR)-dependent and IR-independent phosphorylation of SMC3. J Biol Chem 2008;283:19176-83.

[21] Smogorzewska A, Matsuoka S, Vinciguerra P, McDonald III ER, Hurov KE, Luo J, et al. Identification of the FANCI protein, a monoubiquitinated FANCD2 paralog required for DNA repair. Cell 2007;129:289-301.

[22] Riches LC, Lynch AM, Gooderham NJ. Early events in the mammalian response to DNA double-strand breaks. Mutagenesis 2008;23:331-9.

[23] Jungmichel S, Stucki M. MDC1: The art of keeping things in focus. Chromosoma 2010;119:337-49.

[24] Jiang J, Yu H, Shou Y, Neale G, Zhou S, Lu T, et al. Hemgn is a direct transcriptional target of HOXB4 and induces expansion of murine myeloid progenitor cells. Blood 2010;116:711-9.

[25] Yang LV, Wan J, Ge Y, Fu Z, Kim SY, Fujiwara Y, et al. The GATA site-dependent hemogen promoter is transcriptionally regulated by GATA1 in hematopoietic and leukemia cells. Leukemia 2006;20:417-25.

[26] Li CY, Zhan YQ Li W, Xu CW, Xu WX, Yu DH, et al. Overexpression of a hematopoietic transcriptional regulator EDAG induces myelopoiesis and suppresses lymphopoiesis in transgenic mice. Leukemia 2007;21:2277-86.

[27] Ow SY, Salim M, Noirel J, Evans C, Rehman I, Wright PC. iTRAQ underestimation in simple and complex mixtures: "the good, the bad and the ugly". J Proteome Res 2009;8: 5347-55.

[28] Li CY, Zhan YQ Xu CW, Xu WX, Wang SY, Lv J, et al. EDAG regulates the proliferation and differentiation of 
hematopoietic cells and resists cell apoptosis through the activation of nuclear factor-kappa B. Cell Death Differ 2004;11:1299-308.

[29] Owen HR, Elser M, Cheung E, Gersbach M, Kraus WL, Hottiger MO. MYBBP1a is a novel repressor of NF-kappa B. J Mol Biol 2007;366:725-36.

[30] Xiao A, Li H, Shechter D, Ahn SH, Fabrizio LA, Erdjument-Bromage $\mathrm{H}$, et al. WSTF regulates the H2A.X DNA damage response via a novel tyrosine kinase activity. Nature 2009;457:57-U.

[31] Cook PJ, Ju BG, Telese F, Wang X, Glass CK, Rosenfeld MG. Tyrosine dephosphorylation of H2AX modulates apoptosis and survival decisions. Nature 2009;458:591-U53.

[32] Loyola A, Tagami H, Bonaldi T, Roche D, Quivy JP, Imhof A, et al. The HP1 alpha-CAF1-SetDB1-containing complex provides $\mathrm{H} 3 \mathrm{~K} 9 \mathrm{me} 1$ for Suv39-mediated K9me3 in pericentric heterochromatin. EMBO Rep 2009;10:769-75.

[33] Ball Jr AR, Yokomori K. Revisiting the role of heterochromatin protein 1 in DNA repair. J Cell Biol 2009;185:573-5.

[34] Noon AT, Shibata A, Rief N, Loebrich M, Stewart GS, Jeggo PA, et al. 53BP1-dependent robust localized KAP-1

phosphorylation is essential for heterochromatic DNA double-strand break repair. Nat Cell Biol 2010;12:177-U91.

[35] Liu CC, Chou YL, Ch'ang LY. Down-regulation of human NDR gene in megakaryocytic differentiation of erythroleukemia K562 cells. J Biomed Sci 2004;11:104-16.

[36] Xie A, Hartlerode A, Stucki M, Odate S, Puget N, Kwok A, et al. Distinct roles of chromatin-associated proteins MDC1 and 53BP1 in mammalian double-strand break repair. Mol Cell 2007;28:1045-57. 